\title{
BIOLOGI REPRODUKSI IKAN JUARO (Pangasius polyuranodon) DI DAERAH ALIRAN SUNGAI MUSI, SUMATRA SELATAN
}

\author{
Yunizar Ernawati', Eko Prianto², dan A. Ma'suf ${ }^{1}$ \\ 1 Dosen Departemen MSP, FPIK-IPB; \\ 2 Balai Riset Perikanan Perairan Umum Palembang
}

\begin{abstract}
Study on biology reproduction was expected to give basic information for management, such as for aquaculture, capture fisheries and conservation of P. polyuranodon in Musi river. Sampling were conducted on June 2006, August 2006, January 2007, and July 2007 in Musi river by using gillnet. Data analysis included length-weight relationship, sex ratio, condition factor, gonad maturity stage, Gonadosomatic Index (GSI), fecundity, and spawning type. Total number of collected P. polyuranodon was 51, consisted of 23 male and 28 female. Total length of fish was ranged in $85-511 \mathrm{~mm}$. Length-weight relationship of male and female was $\mathrm{W}=0.00002 \mathrm{~L}^{2.8062}$ and $W=0.0002 L^{2.8215}$ respectively. The result from $t$-test analysis showed that both of sexes have allometric negative growth. Sex ratio thoroughly was balance (1:1). Mean of factor condition relatively increased by the increasing of gonad maturity stage. At that time P. polyuranodon was entering spawning time. June and August was predicted as the spawning time of this species. Gonadosomatic index of female was much higher than the male. Fecundity of female was ranged between 616 and 7,059. Based on distribution of egg diameter, this species was total spawner.
\end{abstract}

Key words: juaro fish, IKG, spawning pattern, $T K G$

\section{PENGANTAR}

Sungai Musi merupakan sungai terbesar di Sumatra Selatan, membelah Kota Palembang menjadi dua bagian, yaitu daerah Seberang Ulu dan daerah Seberang Ilir. Panjang Sungai Musi $\pm 759 \mathrm{~km}$ dengan debit bervariasi antara $2.700 \mathrm{~m}^{3} /$ detik pada musim kemarau dan mencapai $4.000 \mathrm{~m}^{3} /$ detik pada musim penghujan (Widiastuti, 2001). Daerah Aliran Sungai (DAS) Musi secara keseluruhan membentang di antara $1^{\circ} 40^{\prime}-5^{\circ}$ Lintang Selatan (LS) dan $102^{\circ} 7^{\prime}-105^{\circ} 7^{\prime}$ Bujur Timar (BT), sedangkan luas DAS Musi hadala $59.870 \mathrm{~km}^{2}$, merupakan $64,3 \%$ dari luas seluruh Provinsi Sumatra.

Menurut Departemen Kelautan dan Perikanan (2007) dalam http://www.dkp.go.id (2007) menginformasikan bahwa sumber daya perikanan di perairan umum Provinsi Sumatra Selatan memiliki potensi yang besar. Salah satu perairan umum yang ada adalah Sungai Musi. Produksi ikan dari penangkapan di perairan umum pada tahun 2005 sebesar 43.059,32 ton. Ikan juaro merupakan salah satu spesies yang banyak ditangkap.

Ikan Juaro jumlahnya cukup banyak di perairan Sungai Musi, namun ikan ini bukan merupakan ikan konsumsi utama. Ikan ini biasanya ikut tertangkap saat nelayan menangkap ikan lainnya, namun masih ada beberapa masyarakat yang mengkonsumsi ikan juaro.

Permasalahan yang muncul dewasa ini adalah adanya aktivitas masyarakat dan industri-industri yang memanfaatkan perairan Sungai Musi untuk pembuangan limbah sehingga dapat mencemari perairan Sungai Musi. Tercemarnya suatu perairan akan mengakibatkan terganggunya keseimbangan ekosistem di perairan tersebut sehingga dikhawatirkan mengancam populasi ikan yang ada didalamnya, salah satunya ikan juaro. Oleh karena itu, perlu dilakukan penelitian untuk memperoleh informasi tentang sumber daya ikan tersebut, salah satunya adalah aspek reproduksi yang dapat berguna bagi pengelolaan dan kelestarian sumber daya perikanan di ekosistem perairan Sungai Musi.

Penelitian ini bertujuan mengetahui aspek biologi reproduksi ikan juaro di Sungai Musi, Sumatra Selatan. Hasil penelitian ini diharapkan dapat menjadi salah satu informasi dalam pengelolaan serta untuk kepentingan budi daya sehingga mampu menjamin kelestarian sumber daya perikanan di perairan Sungai Musi.

\section{BAHAN DAN CARA KERJA}

\section{Waktu dan Lokasi Penelitian}

Penelitian dilakukan pada bulan Juni 2006, Agustus 2006, Januari 2007 dan Juli 2007 di Daerah Aliran Sungai (DAS) Musi. Pengambilan contoh ikan dilakukan pada 13 stasiun yang tersebar di sepanjang DAS Musi dari hulu hingga ke hilir. Analisis terhadap ikan contoh dilakukan di Laboratorium Biomakro dan Biomikro Bagian Ekobiologi Perairan, Departemen Manajemen Sumber daya Perairan, Fakultas Perikanan dan Ilmu Kelautan, Institut Pertanian Bogor. 


\section{Alat dan Bahan}

Untuk menangkap ikan digunakan jala dan jaring insang (experimental gillnet) dengan 4 ukuran mata jaring, yaitu 0,$5 ; 1 ; 1,5 ;$ dan 2 inci untuk contoh yang diambil pada bulan Juni 2006, Agustus 2006, dan Januari 2007. Pengambilan contoh bulan Juli 2007 menggunakan 8 ukuran mata jaring, yaitu 0,$75 ; 1 ; 1,25 ; 1,5 ; 1,75 ; 2 ; 2,25$; dan 2,5 inci, dengan panjang jaring masing-masing 10 meter. Beberapa jenis alat tangkap yang digunakan dalam pengambilan ikan contoh adalah ember plastik, botol film/plastik, penggaris dengan ketelitian $0,1 \mathrm{~cm}$, timbangan digital dengan ketelitian 0,01 gram, alat bedah, mikroskop binokuler, mikrometer okuler, pipet tetes, gelas ukur, gelas objek dan gelas penutup. Ikan contoh diawetkan dengan menggunakan formalin $10 \%$ dan formalin $4 \%$ untuk mengawetkan gonad ikan contoh.

\section{Analisis Data}

Penghitungan jumlah kelas ukuran ikan contoh menggunakan rumus Sturges (Sugiyono, 2003), yakni: $\mathrm{K}=1+(3,32 \times \log \mathrm{n}), \mathrm{K}$ adalah jumlah kelas ukuran, $\mathrm{n}$ adalah jumlah data pengamatan. Setelah itu dilakukan analisis hubungan panjang-berat untuk mengetahui pola pertumbuhan ikan dengan menggunakan rumus $\mathrm{W}=a L^{b}$, $\mathrm{W}$ adalah berat ikan (gram), L adalah panjang total ikan $(\mathrm{mm})$, serta a dan $\mathrm{b}$ adalah konstanta.

Faktor kondisi dihitung berdasarkan pola pertumbuhan panjang total dan berat total tubuh ikan. Bila pola pertumbuhannya isometrik maka faktor kondisi ikan dihitung dengan rumus $\mathrm{K}=\frac{10^{5} \mathrm{~W}}{\mathrm{~L}^{3}}$ (Effendie, 1979), $\mathrm{K}$ adalah faktor kondisi, $\mathrm{W}$ adalah berat ikan dan $\mathrm{L}$ adalah panjang total ikan (mm), sedangkan bila pola pertumbuhannya alometric maka penghitungan faktor kondisi menggunakan rumus $\mathrm{K}=\frac{\mathrm{W}}{\mathrm{a} \mathrm{L}^{\mathrm{b}}}, \mathrm{K}$ adalah faktor kondisi, $\mathrm{W}$ adalah berat ikan, $\mathrm{L}$ adalah panjang total ikan (mm), serta a dan b adalah konstanta.

\section{Aspek Reproduksi}

Rasio kelamin dihitung dengan rumus $\mathrm{x}=\frac{\mathrm{M}}{\mathrm{F}}$, $\mathrm{x}$ adalah rasio kelamin, $\mathrm{M}$ adalah jumlah ikan jantan (ekor), dan $\mathrm{F}$ adalah jumlah ikan betina (ekor). Keseragaman sebaran rasio kelamin dianalisis dengan uji "Chi-Square" (Steel dan Torie 1980), $\mathrm{X}^{2}=\frac{\sum\left(o_{i}-e_{i}\right)}{e_{i}}, \mathrm{X}^{2}$ adalah nilai peubah acak $\mathrm{X}^{2}$ yang sebaran penarikan contohnya mendekati sebaran Chi-square, $\mathrm{o}_{\mathrm{i}}$ adalah frekuensi ikan jantan dan betina ke-i yang diamati, $\mathrm{e}_{\mathrm{i}}$ adalah frekuensi harapan, yaitu frekuensi ikan jantan + frekuensi ikan betina dibagi dua.

\section{Tingkat Kematangan Gonad (TKG)}

TKG ditentukan secara morfologi berdasarkan analisis ukuran, bentuk, warna, butiran minyak dan pengisian dalam rongga perut yang dilakukan sendiri, dan secara histologi (Banks, 1986). Ukuran rata-rata ikan juaro pertama kali matang gonad menggunakan metode Spearman-Karber (Udupa dalam Yulianti, 2003), yakni $\mathrm{m}=\mathrm{xk}+[\mathrm{x} / 2]-\left(\mathrm{x} \sum \mathrm{p}_{\mathrm{i}}\right), \mathrm{m}$ adalah log panjang ikan pada kematangan gonad pertama, $\mathrm{xk}$ adalah log nilai tengah kelas panjang yang terakhir ikan telah matang gonad, $\mathrm{x}$ adalah log pertambahan panjang pada nilai tengah, $\mathrm{p}_{\mathrm{i}}$ adalah proporsi ikan matang gonad pada kelas panjang ke-i dengan jumlah ikan pada selang panjang ke-i.

\section{Indeks Kematangan Gonad (IKG)}

Nilai indeks kematangan gonad (IKG) dihitung dengan menggunakan rumus $\mathrm{IKG}=\frac{\mathrm{M}}{\mathrm{F}} \times 100 \%, \mathrm{IKG}$ adalah Indeks kematangan gonad, Bg adalah berat gonad (g), dan $\mathrm{W}$ adalah berat tubuh total (g).

\section{Fekunditas}

Fekunditas dihitung dengan menggunakan metode volumetrik dan gravimetrik (Effendie, 1979), rumusnya adalah $\mathrm{F}=\frac{G \times V \times X}{Q}, \mathrm{~F}$ adalah Fekunditas, $\mathrm{G}$ adalah berat gonad $(\mathrm{g}), \mathrm{V}$ adalah volume pengeceran $(\mathrm{ml}), \mathrm{X}$ adalah jumlah telur tiap $\mathrm{ml}$ (butir) dan $\mathrm{Q}$ adalah berat telur contoh (g).

\section{HASIL}

\section{Sebaran Frekuensi Ikan Juaro}

Jumlah ikan juaro yang diperoleh selama masa pengambilan sampel (Juni 2006, Agustus 2006, Januari 2007 dan Juli 2007) berjumlah 51 ekor, di antaranya 23 ekor ikan jantan dan 28 ekor ikan betina, setelah dilakukan analisis diperoleh 7 kelas ukuran panjang total, kisaran panjang ikan jantan dan betina berkisar antara 85-511 mm. frekuensi ikan jantan tersebar pada selang kelas ukuran 85-389 mm, sedangkan ikan betina tersebar pada selang kelas ukuran $85-511 \mathrm{~mm}$. untuk frekuensi ikan jantan terbanyak berada pada selang kelas ukuran 146-206 $\mathrm{mm}$, yaitu sebanyak 10 ekor sedangkan untuk frekuensi ikan betina terbanyak berada pada selang kelas ukuran 85-145 mm, yakni sebanyak 7 ekor (Gambar 1). 

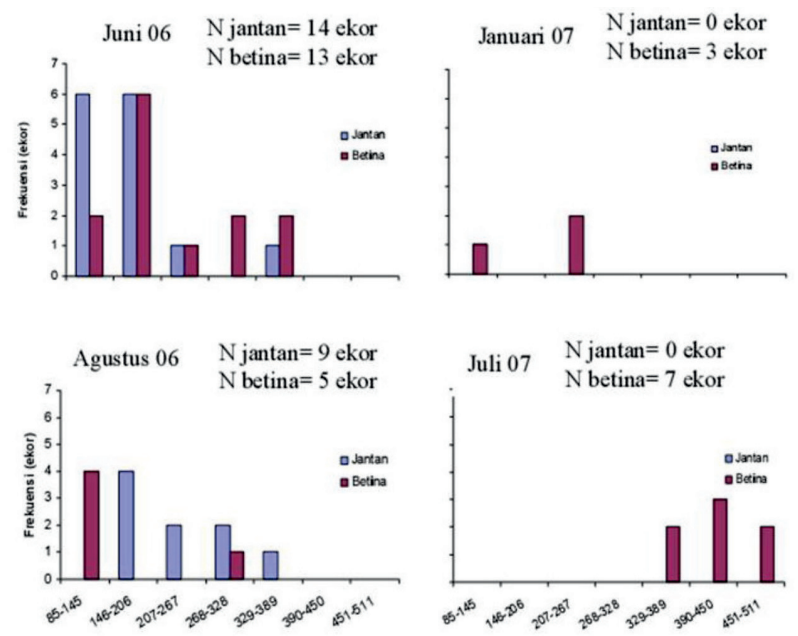

Gambar 1. Sebaran frekuensi ikan juaro (P. polyuranodon) setiap selang kelas $(\mathrm{mm})$, jenis kelamin dan bulan penelitian

Sebaran ikan juaro dibedakan menjadi tiga kelompok, yaitu kelompok ukuran kecil (85-206 mm), sedang (207$389 \mathrm{~mm}$ ), dan besar (390-511 mm). Setelah dilakukan analisis hubungan panjang berat ikan juaro jantan adalah $\mathrm{W}=0,0002 \mathrm{~L}^{2,8062}$ dengan nilai b sebesar 2,8062 , sedangkan untuk ikan Juaro betina adalah $\mathrm{W}=0,00002 \mathrm{~L}^{2,8215}$ dengan nilai $b$ sebesar 2,8215 . dari hasil analisis hubungan panjangberat diperoleh nilai koefisien korelasi (r) yang tinggi, baik pada ikan juaro jantan $(0,9827)$ maupun ikan juaro betina $(0,9536)$ (Gambar 2). Berdasarkan hasil uji t diperoleh hasil bahwa pola pertumbuhan ikan juaro jantan maupun betina adalah alometrik negatif, yaitu pertambahan nilai panjang tubuh ikan lebih cepat daripada pertumbuhan nilai berat tubuh ikan.

\section{Rasio Kelamin Ikan Juaro}

Ikan Juaro yang diperoleh selama penelitian berjumlah 51 ekor terdiri dari 28 ekor ikan betina dan 23 ekor ikan jantan dengan rasio kelamin $1: 0,82$. Berdasarkan tiap bulan pengambilan ikan contoh nilai rasio kelamin berkisar antara $0-1,80$. Rasio kelamin tertinggi diperoleh pada bulan Agustus 2006 yaitu sebesar 1,80, dan rasio kelamin terendah dengan nilai 0 pada bulan Januari dan Juli 2007 (Gambar 3). berdasarkan selang kelas panjang total diperoleh rasio kelamin $(1: 1)$, yaitu pada selang kelas panjang total $207-267 \mathrm{~mm}$. Rasio kelamin pada selang kelas panjang total tersebut adalah 1 dengan frekuensi ikan jantan dan betina masing-masing sebanyak 3 ekor. Rata-rata pada setiap kelas panjang total, didominasi oleh ikan juaro betina, hal ini terlihat dari rasio kelamin kurang dari 1, namun pada selang kelas panjang total $146-206 \mathrm{~mm}$ didominasi oleh ikan jantan.

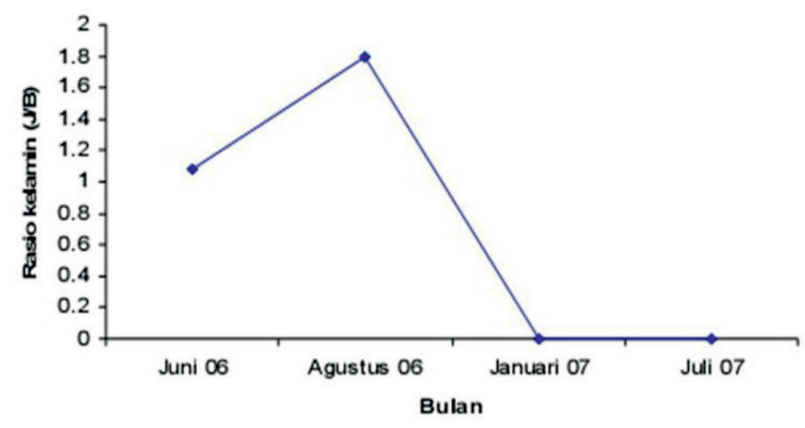

Gambar 3. Rasio kelamin ikan juaro (P. polyuranodon) di setiap bulan pengamatan

\section{Faktor Kondisi Ikan Juaro}

Faktor kondisi ikan juaro jantan mempunyai kisaran antara 0,6999-1,3061 dan ikan juaro betina berkisar antara 0,5194-4,1929. Faktor kondisi tertinggi ikan juaro jantan terjadi pada bulan Agustus 2006 sebesar 1,3061 (Gambar 4). Faktor kondisi tertinggi ikan juaro betina terjadi pada bulan Januari 2007 sebesar 4,1929.
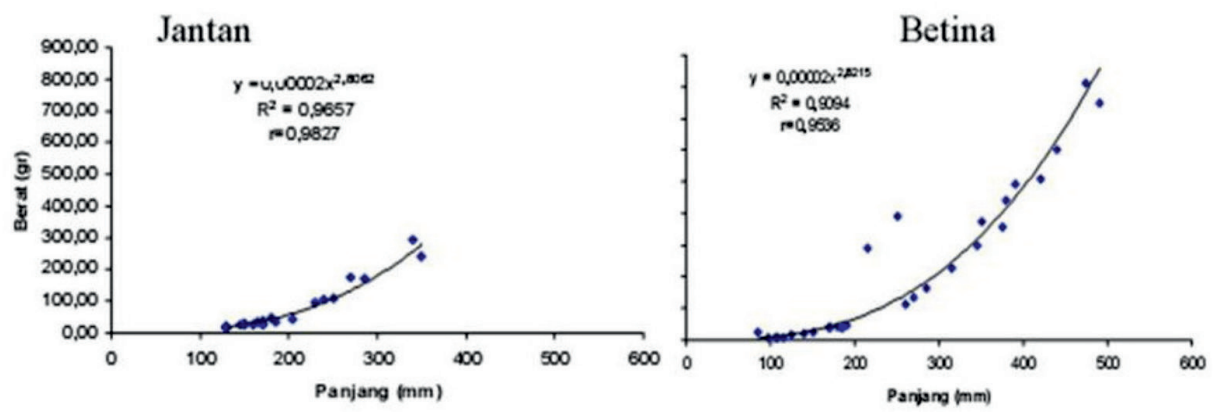

Gambar 2. Hubungan panjang berat ikan juaro (P. polyuranodon) jantan dan betina 


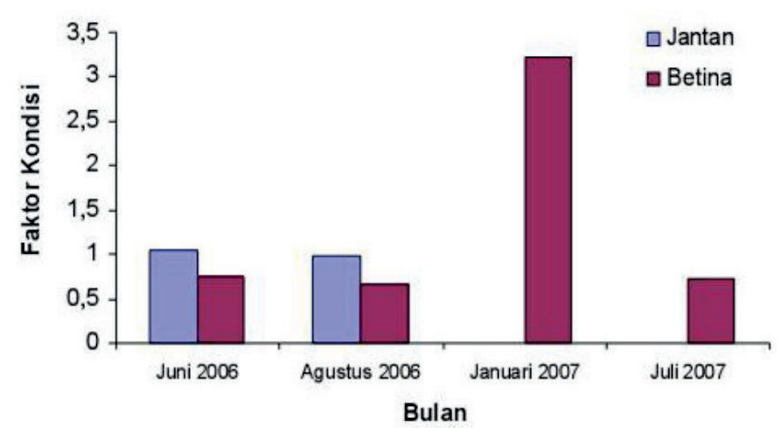

Gambar 4. Rata-rata faktor kondisi ikan juaro (P. Polyuranodon) jantan dan betina setiap bulan pengamatan

\section{Tingkat Kematangan Gonad (TKG)}

Tingkat kematangan gonad ditentukan melalui pengamatan morfologi dan histologi. Secara histologi pada gonad jantan TKG I sel spermatogonium tidak terlihat jelas, karena tertutup oleh kantung tubulus seminiferus pada pembesaran 400 kali. Pada TKG II gonad lebih berkembang, kantung tubulus seminiferus sudah mulai diisi oleh spermatosit primer. Kemudian pada TKG III spermatosit primer berubah menjadi spermatosit sekunder, dan pada TKG IV spermatosit sudah menyebar, kemudian berkembang menjadi spermatid dan spermatozoa (Gambar 5).
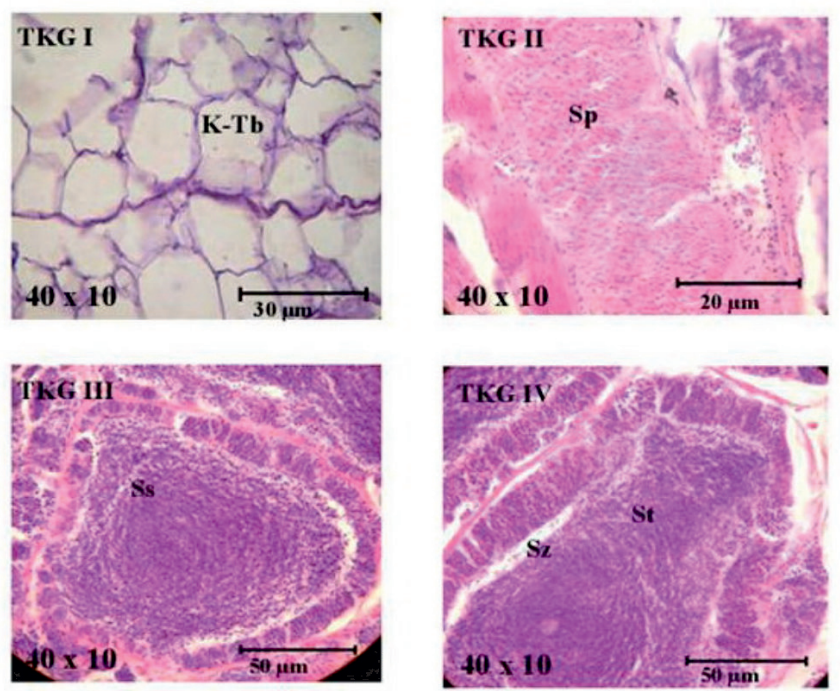

Gambar 5. Histologi testis ikan juaro (P. polyuranodon). Ket: K-Tb: kantung tubulus; Sp: spermatosit primer; Ss: spermatosit sekunder; St: Spermatid; Sz: spermatozoa.

Pada gonad betina TKG I didominasi oleh oogonium dan sedikit oosit. Pada TKG II ukuran sel telur bertambah besar, didominasi oleh oosit dan ukuran nukleus yang besar.
Pada TKG III sel telur berkembang menjadi ootid dan diameter telur semakin membesar. Kuning telur dan butiran minyak sudah terbentuk. Pada TKG IV ootid berkembang menjadi ovum (Gambar 6).
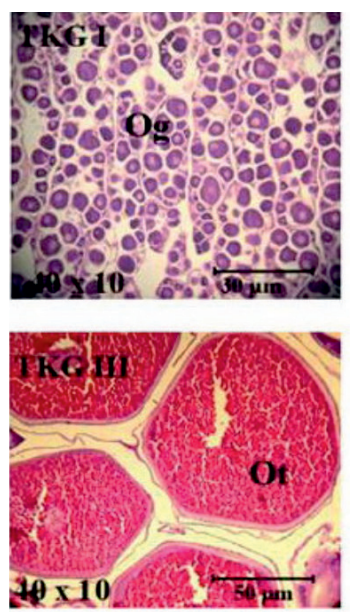
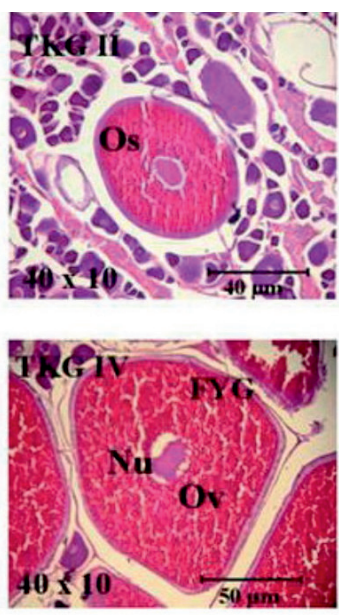

Gambar 6. Histologi ovarium ikan juaro (P. polyuranodon). Ket: Og: oogonia; Os: oosit; Ot: ootid; FYG: butir kuning telur; Ov: ovum; Nu: nukleus.

Frekuensi tertinggi ikan juaro jantan dan betina terdapat pada selang kelas panjang total $146-206 \mathrm{~mm}$, yaitu masingmasing berjumlah 7 ekor dan 5 ekor. Ikan jantan TKG II terdapat pada 3 selang kelas panjang total, yakni 85-145 $\mathrm{mm}, 146-206$, dan 207-267 mm, masing-masing berjumlah 1 ekor, sedangkan frekuensi tertinggi ikan betina TKG II terdapat pada selang kelas panjang total $207-267 \mathrm{~mm}$ dengan jumlah 3 ekor. Ikan jantan TKG III frekuensi tertinggi terdapat pada selang kelas panjang total 146-206 mm sebanyak 2 ekor, sedangkan frekuensi tertinggi ikan betina TKG III terdapat pada selang kelas panjang total 85-145 mm sebanyak 2 ekor. Ikan jantan TKG IV terdapat pada selang kelas panjang total $268-328 \mathrm{~mm}$, masingmasing 1 ekor, sedangkan ikan betina TKG IV frekuensi tertinggi terdapat pada selang kelas panjang total 329-389 mm sebanyak 4 ekor.

Frekuensi tertinggi ikan jantan TKG I terdapat pada bulan Juni 2006 sebanyak 11 ekor, begitupun dengan ikan betina pada TKG dan bulan yang sama sebanyak 7 ekor (Gambar 7). Berdasarkan hasil analisis pendugaan ukuran pertama kali ikan matang gonad dengan metode SpearmenKarber, ikan juaro jantan diduga pertama kali matang gonad pada kisaran panjang total $309-347 \mathrm{~mm}$. Ukuran pertama kali matang gonad pada ikan juaro betina diduga pada panjang total $159-355 \mathrm{~mm}$. 


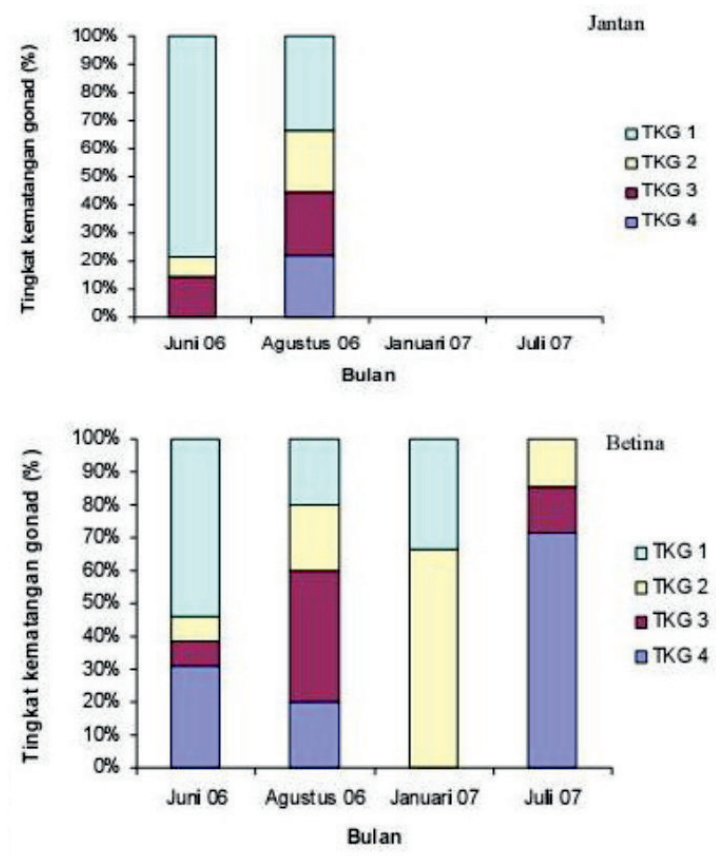

Gambar 7. Tingkat Kematangan Gonad (\%) ikan juaro (P. polyuranodon) pada setiap bulan pengamatan

\section{Indeks Kematangan Gonad (IKG)}

Ikan jantan memiliki rata-rata indeks kematangan gonad berkisar antara $0,14-0,3 \%$, sedangkan pada ikan betina nilainya berkisar antara $0,16-7,45 \%$. Rata-rata indeks kematangan gonad tertinggi terdapat pada bulan Agustus 2006, yaitu sebesar 7,45\%. Berdasarkan tingkat kematangan gonad, ikan juaro jantan memiliki rata-rata indeks kematangan gonad berkisar antara $0,08-8,21 \%$. Hasil analisis indeks kematangan gonad berdasarkan bulan pengambilan ikan contoh dan tingkat kematangan gonad menunjukkan bahwa ikan betina memiliki rata-rata indeks kematangan gonad yang lebih besar dibandingkan dengan ikan jantan (Gambar 8).

\section{Fekunditas}

Fekunditas ikan juaro diperoleh berdasarkan analisis 14 sampel gonad yang sudah masak, TKG III (4 gonad) dan TKG IV (10 gonad). Jumlah telur yang didapatkan setelah dilakukan pengamatan berkisar antara 616-7.059 butir telur. Jumlah telur ikan juaro dengan frekuensi terendah ditemukan pada ikan dengan panjang tubuh total $391 \mathrm{~mm}$ sebanyak 616 butir telur (TKG IV), sedangkan jumlah telur dengan frekuensi tertinggi ditemukan pada ikan dengan panjang tubuh total $285 \mathrm{~mm}$ sebanyak 7.059 butir pada TKG yang sama. Berdasarkan hasil regresi fekunditas dengan panjang tubuh diperoleh koefisien determinasi sebesar 0,0766, dan didapat nilai koefisien korelasi (r) sebesar 0,277 (Gambar 9).

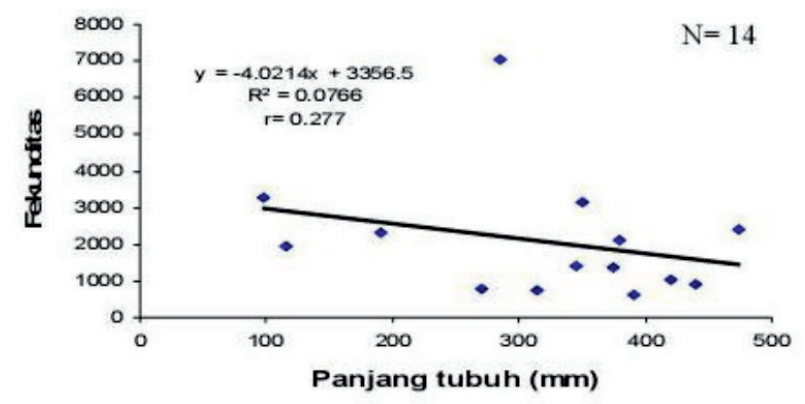

Gambar 9. Hubungan panjang total ikan juaro (P. polyuranodon) dengan fekunditas (TKG III dan IV)

\section{Diameter Telur Ikan Juaro}

Jumlah gonad yang masak ikan Juaro betina seluruhnya berjumlah 14 gonad, terdiri atas 4 TKG III dan 10 TKG IV. Dari 14 gonad tersebut diamati sebaran diameter telur sebanyak 8 gonad, yaitu 4 TKG III dan 4 TKG IV diambil secara acak dari 10 TKG IV yang masak. Kemudian sebaran diameter telur diamati pada masing-masing gonad yang diamati bervariasi mulai dari $0,11-1,85 \mathrm{~mm}$, diperoleh selang kelas sebanyak 12 kelas. Sebaran diameter telur pada

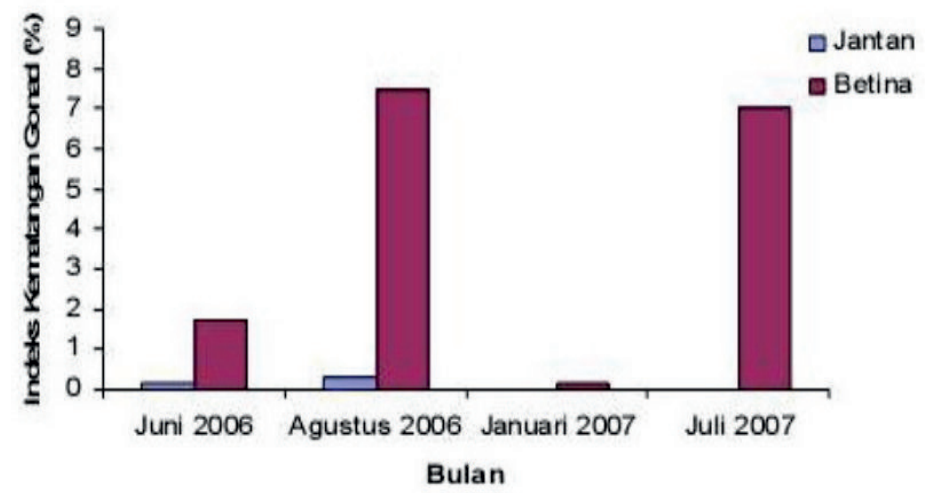

Gambar 8. Rata-rata Indeks Kematangan Gonad (\%) ikan juaro (P. polyuranodon) pada setiap bulan pengamatan 
ikan TKG III yang diamati sebanyak 4 ekor dengan diameter berkisar antara 0,11-1,04 mm, sedangkan sebaran diameter berkisar antara 0,38-1,85 $\mathrm{mm}$ (Gambar 10).
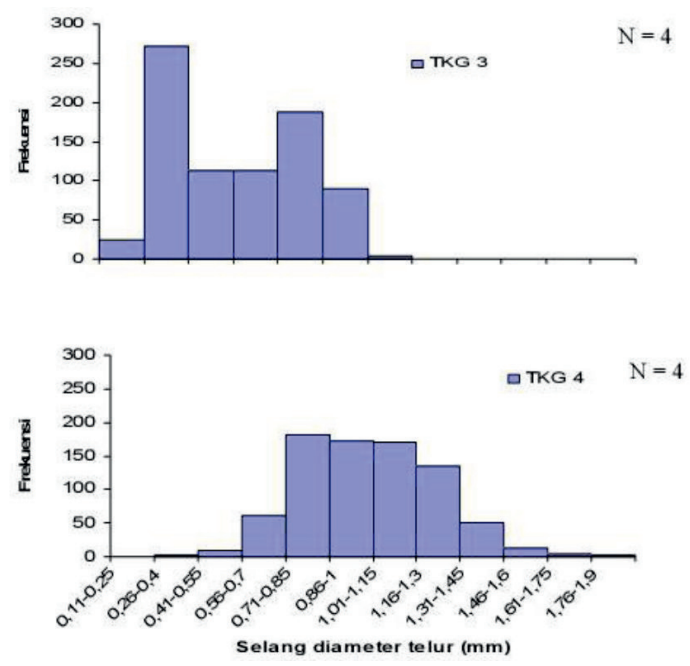

Gambar 10. Sebaran diameter telur ikan juaro (P. polyuranodon) pada TKG III dan TKG IV

\section{PEMBAHASAN}

Panjang total tubuh dari ikan juaro sangat memengaruhi berat total tubuh ikan tersebut, artinya semakin besar nilai panjang total tubuh ikan maka semakin besar pula nilai berat total tubuh ikan tersebut. Menurut Walpole (1995), apabila nilai koefisien korelasi (r) mendekati 1 maka menunjukkan hubungan yang sangat erat antara kedua peubah dan dapat dikatakan terdapat korelasi yang tinggi antara keduanya.

Diperolehnya nilai rasio kelamin 0 disebabkan pada bulan Januari dan Juli 2007 tidak ada ikan jantan yang tertangkap. Hasil uji Chi-square rasio kelamin secara keseluruhan dan berdasarkan selang kelas panjang total pada taraf nyata 0,05 menunjukkan bahwa rasio kelamin ikan juaro di Sungai Musi seimbang. Namun, berdasarkan pada bulan pengambilan ikan contoh uji Chi-square rasio kelamin menunjukkan hasil sebaliknya. Perbedaan hasil tersebut sesuai dengan pernyataan Effendie (2002) bahwa pada kenyataannya di alam, perbandingan rasio kelamin tidaklah mutlak, hal ini dipengaruhi oleh pola distribusi yang disebabkan oleh ketersediaan makanan, kepadatan populasi, dan keseimbangan rantai makanan.

Faktor kondisi tertinggi ikan juaro jantan terjadi pada bulan Agustus 2006 karena pada saat itu ditemukan ikan jantan dengan tingkat kematangan gonad yang lengkap, yakni TKG I-TKG IV dengan frekuensi yang hampir merata. Hal ini sesuai dengan pendapat Effendie (1979) bahwa salah satu faktor yang memengaruhi faktor kondisi adalah tingkat kematangan gonad, sedangkan faktor kondisi tertinggi ikan juaro betina terjadi pada bulan Januari 2007 karena pada waktu tersebut ikan yang tertangkap memiliki rentang kelas ukuran yang sangat jauh. Hal ini menunjukkan bahwa umur ikan yang tertangkap di bulan tersebut memiliki rentang yang jauh sehingga hal tersebut memengaruhi nilai faktor kondisi ikan di bulan tersebut. Hal ini juga sesuai dengan pendapat Effendie (1979) bahwa salah satu faktor yang memengaruhi faktor kondisi adalah umur ikan.

Dalam (Ernawati, 1999) dijelaskan bahwa dari bentuk histologi suatu ikan dapat ditentukan pola pemijahannya, jika pada tiap perkembangan sel dari suatu TKG masih terlihat bagian sel TKG sebelumnya, maka ikan tersebut umumnya memiliki tipe pola pemijahan partial spawner (mengeluarkan telur yang masak tidak dalam satu waktu), namun jika tidak terlihat maka ikan tersebut memiliki tipe pola pemijahan total spawner (mengeluarkan telur yang masak dalam satu waktu). Jika dilihat dari bentuk histologinya maka ikan juaro memiliki tipe pola pemijahan total spawner.

Tingkat kematangan gonad ikan juaro jantan dan betina hampir semua meningkat seiring dengan bertambahnya nilai selang kelas panjang total. Hal ini menunjukkan bahwa bertambahnya panjang tubuh ikan, maka akan meningkatkan tingkat kematangan gonad, diduga ikan Juaro seimbang dalam menggunakan energi baik untuk pertumbuhan maupun perkembangan gonadnya.

Berdasarkan bulan pengambilan ikan contoh diperoleh bahwa ikan juaro jantan didominasi oleh ikan TKG I, begitupun dengan ikan betina. Ukuran pertama matang gonad antara ikan jantan dan ikan betina berbeda. Sesuai dengan pendapat Effendie (2002) yang menyatakan bahwa ukuran pertama kali matang gonad pada tiap spesies berbeda, begitu pula pada ikan yang sama spesiesnya.

Nilai rata-rata tertinggi Indeks Kematangan Gonad ikan juaro terjadi pada bulan Agustus menunjukkan bahwa bulan tersebut menjadi waktu bagi ikan juaro dalam melakukan pemijahan. Rata-rata indeks kematangan gonad cenderung meningkat seiring dengan peningkatan tingkat kematangan gonad. Hal ini juga sesuai dengan pernyataan Effendie (2002) bahwa ada hubungan antara indeks kematangan gonad akan meningkat seiring dengan meningkatnya tingkat kematangan gonad dan akan menurun setelah ikan selesai memijah.

Nilai Indeks Kematangan Gonad ikan betina lebih besar daripada ikan jantan. Hal ini dikarenakan ikan betina yang tertangkap selama empat bulan pengambilan ikan contoh memiliki gonad yang lebih berkembang dibandingkan 
dengan ikan jantan. Perkembangan gonad tersebut seiring dengan peningkatan berat gonad yang kemudian memengaruhi nilai rata-rata indeks kematangan gonad. Indeks kematangan gonad akan semakin meningkat seiring dengan peningkatan berat gonad ikan tersebut (Effendie, 2002).

Hasil regresi antara fekunditas dan panjang total menunjukkan bahwa hanya $7,66 \%$ dari keragaman nilai fekunditas ikan juaro dapat dijelaskan oleh panjang tubuh total. Dari hasil regresi tersebut juga dapat disimpulkan bahwa terdapat hubungan yang kurang erat antara fekunditas dengan panjang tubuh. Effendie (2002) menyatakan bahwa fekunditas suatu jenis ikan berhubungan erat dengan lingkungannya, dalam hal ini fekunditas dari suatu spesies ikan akan berubah bila keadaan lingkungannya berubah. Hal ini berkaitan dengan kelimpahan makanan yang tersedia dalam lingkungan tersebut. Sehingga fekunditas lebih sering dihubungkan dengan panjang daripada berat, karena panjang penyusutannya lebih kecil dibandingkan dengan berat yang dapat dengan mudah berkurang apabila terjadi perubahan lingkungan dan kondisi fisiologis pada ikan.

Berdasarkan sebaran diameter telur diduga pola pemijahan ikan juaro adalah total spawner, yaitu ikan juaro melakukan pemijahan hanya sekali dalam setahun dengan mengeluarkan telur yang masak sekaligus dalam satu waktu. Hal ini terlihat dari sebaran diameter telur TKG IV yang membentuk 1 puncak (Gambar 10).

\section{Pengelolaan Sumber daya Ikan Juaro}

Pengelolaan terhadap sumber daya perikanan di perairan Sungai Musi perlu dilakukan untuk menjaga keseimbangan ekosistem baik untuk saat ini maupun masa yang akan datang. Perairan Sungai Musi kaya akan sumber daya perikanan, di mana semuanya itu perlu diperhatikan kelestariannya, khususnya ikan juaro. Beberapa aspek biologi yang dapat membantu pengelolaan antara lain adalah evaluasi terhadap kapasitas dan potensi perairan serta pengetahuan tentang perubahan-perubahan besarnya atau jumlah stok (Effendie, 2002). Dari beberapa aspek biologi tersebut di antaranya adalah aspek biologi reproduksi yang dapat bermanfaat demi kelestarian sumber daya perikanan di perairan Sungai Musi.

Pengelolaan sumber daya ikan juaro di Sungai Musi ditujukan pada upaya untuk menjamin kelestarian stok ikan tersebut di perairan Sungai Musi melalui pendekatan aspek biologi reproduksinya. Reproduksi dari suatu jenis ikan sangat berkaitan dengan populasi ikan tersebut dialam.

Berdasarkan hasil penelitian ini dihasilkan beberapa informasi yang diharapkan dapat mendukung kegiatan pengelolaan sumber daya ikan juaro lebih lanjut, di antaranya ikan Juaro memiliki pola pertumbuhan allometrik negatif untuk ikan jantan dan betina, rasio kelamin ikan juaro secara keseluruhan selama penelitian seimbang $(1: 1)$. Rata-rata faktor kondisi ikan juaro cenderung meningkat seiring dengan meningkatnya tingkat kematangan gonad. Ikan juaro telah memasuki waktu memijah diduga sekitar bulan JuniAgustus. Ikan juaro betina memiliki indeks kematangan gonad yang lebih besar dibandingkan dengan ikan jantan. Fekunditas ikan juaro setelah dilakukan pengamatan berkisar antara 616-7.059 butir telur, dan memiliki pola pemijahan total spawner.

Informasi yang diperoleh di atas, diharapkan dapat menjadi informasi yang penting bagi upaya pengelolaan ikan juaro. Adapun upaya yang dapat dilakukan di antaranya kegiatan domestikasi dan pembudi dayaan, upaya domestikasi dan pembudi dayaan ikan juaro diharapkan dapat meningkatkan populasi dan produksi ikan tersebut.

Keberhasilan usaha domestikasi dan pembudi dayaan ikan juaro ini diharapkan dapat bermanfaat bagi kelestarian ikan juaro itu sendiri, dan dapat bermanfaat untuk alternatif kebutuhan protein hewani yang rendah kolesterol bagi masyarakat khususnya di sekitar perairan Sungai Musi.

Upaya pengelolaan dapat pula dilakukan dengan pengawasan terhadap cara penangkapan yang didasarkan pada pengaturan waktu dan seleksi alat tangkap yang digunakan. Pelarangan waktu seperti pelarangan penangkapan pada musim penghujan karena saat itu merupakan waktu untuk ikan melakukan pemijahan. Seleksi alat tangkap menyangkut pembatasan ukuran mata jaring terutama yang memiliki ukuran mata jaring kecil. Ikan juaro di Sungai Musi ada yang ditangkap dengan menggunakan alat tangkap jala dan jaring dengan ukuran mata jaring 0,5 inci; 1 inci; 1,5 inci; dan 2 inci. Sehingga dengan ukuran tersebut maka ikan juaro dalam ukuran kecil yang sedang dalam masa pertumbuhan akan tertangkap, hal ini akan mengganggu keberlangsungan stok ikan juaro di perairan Sungai Musi. Upaya pengelolaan yang dilakukan untuk mengatasi hal tersebut di atas yakni dengan menggunakan alat tangkap yang memungkinkan tidak tertangkapnya ikan juaro yang sedang dalam masa pertumbuhan. Beberapa usaha lain yang bisa dilakukan di antaranya pengendalian aktivitas penangkapan ikan terutama menjelang masa pemijahan, jumlah armada dan alat tangkap yang digunakan tetap harus dilakukan pemantauan. Kebijakan yang mengatur waktu penangkapan serta alat tangkap yang selektif perlu dikeluarkan oleh stakeholder dan pihakpihak terkait demi adanya suatu regulasi penangkapan yang ramah lingkungan dan tercapainya keseimbangan 
ekosistem di alam. Seiring dengan berkembangnya industri mengakibatkan tercemarnya Sungai Musi, oleh karena itu diperlukan peraturan yang ketat agar beban pencemaran yang masuk ke perairan tidak terlalu besar untuk menjaga kelestarian ekosistem perairan Sungai Musi. Kerja sama masyarakat dan pemerintah untuk menjaga kelestarian biota-biota di Sungai Musi sangat penting karena tanpa adanya kerja sama antara masyarakat dan pemerintah akan menyebabkan gagalnya usaha pengelolaan tersebut.

\section{KEPUSTAKAAN}

Banks WJ, 1986. Applied Veterinary Histology, Second Edition. Louisiana, $503 \mathrm{p}$.

Effendie MI, 1979. Metode Biologi Perikanan. Yayasan Dewi Sri. Bogor.

Effendie MI, 2002. Biologi Perikanan. Yayasan Pustaka Nusantara, Yogyakarta.

Ernawati Y, 1999. Efisiensi Implantasi Analog LH-RH dan 17 $\alpha$-Metiltestosteron serta Pembekuan Semen dalam Upaya
Peningkatan Produksi Benih Ikan Jambal Siam (Pangasius hypophthalmus). Disertasi. Program Pascasarjana. IPB. 119 hal.

Stell RL dan Smith TM, 1980. Principles and Procedures of statistics. a Biometrical Approach. McGraw-Hill. International Book Company.

Sugiyono, 2003. Statistika Untuk Penelitian. CV Alfabeta. Bandung.

Walpole RE, 1995. Pengantar Statistika edisi Ke-3 alih Bahasa oleh Sumantri, B. PT Gramedia Pustaka Utama, Jakarta.

Widiastuti S, 2001. Dampak Pengolahan Limbah Cair PT Pupuk Sriwidjaja terhadap Kualitas Air Sungai Musi Kotamadya Palembang. Tesis. Program Pascasarjana. Institut Pertanian Bogor.

Yulianti Y, 2003. Beberapa Aspek Reproduksi Ikan Lidah (Cynoglosus lingua hamiltin buchana) di Muara Sungai Cimandiri, Teluk Pelabuhan Ratu, Jawa Barat. Skripsi. Manajemen Sumber daya Perairan. Fakultas Perikanan Ilmu Kelautan. IPB, 56 hal. Tidak dipublikasikan.

http://www.dkp.go.id/, 2007, diakses tanggal 30 Desember 2007.

Reviewer: Prof. Dr. Komar 